\title{
The Application of Zeolite to Increase Nitrogen Use Efficiency in Corn Vegetative Growth in Coastal Sandy Soils
}

DOI: $10.18196 /$ pt.2020.107.1-6

\author{
Gunawan Budiyanto \\ Department of Agrotechnology, Faculty of Agriculture, Universitas Muhammadiyah Yogyakarta, \\ Bantul, Yogyakarta 55183, Indonesia \\ email: goenb@yahoo.com
}

\begin{abstract}
Coastal sandy soil is usually dominated by sand fractions, having no micro pore complex that can bind water and store fertilizer nutrients. The application of zeolite rocks into the root zone of plants growing in sandy soil is expected to reduce nitrogen nutrient leaching. The research was carried out by using the greenhouse experiment method, arranged in a factorial completely randomized design. The first factor was activated zeolite rock doses, consisting of 7 levels, namely 0\% (ZO), 1\% (Z1), 2\% (Z2), 3\% (Z3), 4\% (Z4), 5\% (Z5), and 6\% (Z6) per $10 \mathrm{~kg}$ of coastal sandy soils as planting media. Meanwhile, the second factor was nitrogen fertilizer doses, consisting of 3 levels, namely $75 \mathrm{~kg}$ (N1), $100 \mathrm{~kg}$ (N2), and $125 \mathrm{~kg}$ (N3) per hectare. The results showed that the application of zeolite rock to the planting media could increase the growth of corn plants fertilized with nitrogen. The best vegetative growth was obtained when $6 \%$ zeolite per $10 \mathrm{~kg}$ of planting media was applied. The application of 6\% zeolite together with $125 \mathrm{~kg}$ per hectare $\mathrm{N}$ fertilizer resulted in the heaviest fresh plant biomass. The use of zeolite can increase the $\mathrm{N}$-fertilizer uptake efficiency in the vegetative growth of corn plants grown in coastal sand soils. Keywords: Low water retention; Sand fraction dominance; Nitrogen leaching, Aluminosilicate minerals
\end{abstract}

\section{ABSTRAK}

Tanah pasir pantai biasanya didominasi oleh fraksi pasir, sehingga tidak memiliki kompleks pori mikro yang dapat mengikat air dan menyimpan hara pupuk. Aplikasi batuan zeolite ke dalam zona akar tanaman yang tumbuh di tanah pasir diharapkan dapat mengurangi pelindian hara nitrogen. Penelitian ini dilaksanakan menggunakan metode percobaan rumah kaca yang disusun dalam rancangan acak lengkap faktorial. Faktor pertama adalah batuan zeolite teraktifasi terdiri 7 level yaitu 0\%(Z0), 1\%(Z1), 2\%(Z2), 3\%(Z3), 4\%(Z4), 5\%(Z5) dan 6\%(Z6) per berat 10 kg media tanah pasir pantai. Sedangkan faktor kedua adalah pupuk nitrogen yang terdiri 3 level yaitu 75 kg per hektar (N1), 100 kg per hektar (N2) dan 125 kg per hektar (N3). Hasil penelitian menunjukkan bahwa aplikasi batuan zeolite ke dalam media tanam tanah pasir dapat meningkatkan pertumbuhan tanaman jagung yang dipupuk nitrogen. Dosis 6\% zeolite per $10 \mathrm{~kg}$ media tanam tanah pasir pantai menghasilkan pertumbuhan vegetatif paling baik. Kombinasi perlakuan $6 \%$ zeolite dan $125 \mathrm{~kg} \mathrm{~N}$ per hektar menghasilkan biomassa segar tanaman paling berat. Pemanfaatan zeolite dapat meningkatkan efisiensi serapan hara N-pupuk pada pertumbuhan vegetatif tanaman jagung di tanah pasir pantai.

Kata Kunci: Retensi air rendah, dominasi fraksi pasir, pelindian nitrogen, mineral aluminosilikat

\section{INTRODUCTION}

Coastal sandy soil is one form of marginal land that has low productivity. This type of soil contains low available nutrients and has a low ability to store water due to the dominance of sand fraction. Low clay mineral and organic matter content cause the soil not to form aggregates, with a weak structure or even without structure (Bruand et al., 2014), so it does not have soil colloids as nutrient binding complexes.

The coastal sandy soil area of Bugel beach $\mathrm{Ku}$ lon Progo is part of more than 10,000 hectares of sandy beach stretching along the southern coast of Bantul and Kulon Progo. Bugel sandy beach has an area of around 3,000 hectares, and some parts of the area have been used by residents to cultivate various types of agricultural commodities such as watermelons, chilies, corn, and vegetables. One of the main problems of these soils is the low moisture content due to their high infiltration capacity and soil permeability. This condition causes the water not to be able to remain in the pores of the soil, moving out of the rooting zone. This process results in low moisture content in the root zone, thus cannot support plant growth. Hoa et al. (2010) state that sandy soils have many factors that limit agricultural production, including nutrient short- 
ages and low water storage capacity.

Soil dominated by sand fraction with low clay mineral and organic matter content has high porosity and easily escapes water out of the root zone. Therefore, crop cultivation in coastal sand has low nitrogen fertilization efficiency, which is due to the unavailability of colloidal complexes of soils capable of binding nitrogen ions of the fertilizer. Dry coastal sandy soil conditions make the root zone space aerobic and stimulate the transformation of ammonium ions into nitrate ions in the soil solution system, making it easily leached (Budiyanto, 2016). This nitrogen leaching process is an obstacle to successful nitrogen fertilization in coastal sandy soils.

The productivity of sandy soil can be improved by adding materials that can increase water storage capacity. Some treatments include the addition of clay minerals, application of organic matter, mulching, and the use of other materials that can store water. The treatments aim to improve the status of water in the root zone and reduce the rate of gravity water so that it can support the nutrient uptake process. The improvement can also be achieved by adding a soil amendment that can bind water and nutrients and gradually free up nutrients for plants to absorb. Utilization of hydrogel as a soil amendment material in sandy soil by Akhter et al. (2004) proved that the material could delay plant wilting and increase soil moisture content. In addition, Tahir and Marschner (2016) used clay minerals as soil ameliorant that was proven to increase crop production in sandy soils.

One of the soil amendment materials is zeolite rock, a form of a hydrated alumina-silicate compound that has multi structural properties. This mineral has water-absorbing properties and acts as ion exchange. Zeolite can be used in agriculture as a soil softener, nutrient carrier, regulator of nutrient release in soil, and agent to increase the diversity of microorganisms in the soil (Sugiarti and Amiruddin, 2008; Sangeetha and Baskar, 2016; Mahesh et al., 2018). Furthermore, the DirectorGeneral of Food Crops and Horticulture (1998) states that zeolite is able to increase the solubility of dissolved oxygen in paddy fields, maintain soil $\mathrm{pH}$ stability, and fix heavy metals such as $\mathrm{Pb}$ and $\mathrm{Cd}$. The addition of zeolite causes the soil to retain fertilizer cations $\left(\mathrm{NH}_{4}^{+}\right.$-urea and $\left.\mathrm{K}^{+}-\mathrm{KCl}\right)$, thereby making them not easily leached by the movement of gravity water as well as increasing soil CEC and crop yields. In addition, the application of zeolite can also increase nutrient uptake of nitrogen and phosphorus in rice cultivation. (Zheng et al., 2019; Wu et al., 2019).

\section{MATERIALS AND METHODS}

In this research, coastal sandy soils were used as planting media, which were taken from Bugel beach Kulon Progo at a depth of $40 \mathrm{~cm}$. Meanwhile, zeolite rocks were mined from Playen Gunung Kidul. The research was conducted from April to August 2019 in the experimental field of the Faculty of Agriculture, Universitas Muhammadiyah Yogyakarta.

The research was carried out using the greenhouse experiment method, arranged in a completely randomized factorial design (Harsojuwono et al., 2011). The first factor was activated zeolite rock doses, consisting of 7 levels, namely $0 \%$ (ZO), $1 \%(\mathrm{Z1}), 2 \%(\mathrm{Z2}), 3 \%(\mathrm{Z3}), 4 \%$ (Z4), 5\% (Z5), and $6 \%$ (Z6) per $10 \mathrm{~kg}$ of sandy soils as planting media. The second factor was nitrogen fertilizer doses, consisting of 3 levels, namely $75 \mathrm{~kg}$ (N1), $100 \mathrm{~kg}$ (N2), and $125 \mathrm{~kg}(\mathrm{~N} 3)$ per hectare. There were four replications within each treatment combination, resulting in a total of 84 experimental units.

Observation on the growth variables of the corn plants was performed eight weeks after planting or during the vegetative growth phase marked by the 
emergence of primordial flowers. Growth variables observed were plant height, plant stem diameter, and fresh weight and dry weight of plant biomass. The data obtained were analyzed using analysis of variance, followed by Duncan's multiple range test at a level of $5 \%$.

\section{RESULTS AND DISCUSSION}

The effect of zeolite application on water and nitrogen availability can be observed from the vegetative growth of corn plants at eight weeks after planting. The analysis of variance indicated that there was no significant interaction effect of the zeolite and nitrogen fertilizer doses on the plant height (Table 1).

Table 1. Plant Height (cm) at Eight Weeks After Planting

\begin{tabular}{ccccc}
\hline \multirow{2}{*}{$\begin{array}{c}\text { Zeolite } \\
\text { doses (\%) }\end{array}$} & \multicolumn{3}{c}{ Nitrogen fertilizer doses } & \\
\cline { 2 - 4 } & $\begin{array}{c}\text { N1 } \\
(75 \mathrm{~kg} / \mathrm{h})\end{array}$ & $\begin{array}{c}\text { N2 } \\
(100 \mathrm{~kg} / \mathrm{h})\end{array}$ & $\begin{array}{c}\text { N3 } \\
(125 \mathrm{~kg} / \mathrm{h})\end{array}$ & \\
\hline Z0 (0) & 66.45 & 78.75 & 86.50 & $77.23 \mathrm{e}$ \\
Z1 (1) & 95.70 & 112.25 & 100.75 & $102.90 \mathrm{~d}$ \\
Z2 (2) & 110.20 & 124.70 & 125.75 & $120.22 \mathrm{c}$ \\
Z3 (3) & 124.50 & 126.75 & 135.00 & $128.75 \mathrm{bc}$ \\
Z4 (4) & 115.25 & 128.25 & 148.70 & $130.73 \mathrm{bc}$ \\
Z5 (5) & 115.10 & 128.75 & 158.50 & $134.12 \mathrm{~b}$ \\
Z6 (6) & 150.20 & 168.20 & 176.75 & $165.05 \mathrm{a}$ \\
\hline Mean & $111.06 \mathrm{q}$ & $123.93 \mathrm{p}$ & $133.14 \mathrm{p}$ & $(-)$ \\
\hline
\end{tabular}

Remarks: Means followed by the same letters in the same column are not significantly different based on DMRT at $\alpha 5 \%$.

Table 2. Stem Diameter (cm) at Eight Weeks After Planting

\begin{tabular}{|c|c|c|c|c|}
\hline \multirow{2}{*}{$\begin{array}{c}\text { Zeolite } \\
\text { doses (\%) }\end{array}$} & \multicolumn{3}{|c|}{ Nitrogen fertilizer doses } & \multirow[b]{2}{*}{ Mean } \\
\hline & $\begin{array}{c}N 1 \\
(75 \mathrm{~kg} / \mathrm{h})\end{array}$ & $\begin{array}{c}\mathrm{N2} \\
(100 \mathrm{~kg} / \mathrm{h})\end{array}$ & $\begin{array}{c}N 3 \\
(125 \mathrm{~kg} / \mathrm{h})\end{array}$ & \\
\hline $\mathrm{ZO}(0)$ & 1.10 & 1.20 & 1.18 & $1.16 c$ \\
\hline $\mathrm{Z1}(1)$ & 1.20 & 1.25 & 1.15 & $1.20 \mathrm{c}$ \\
\hline $\mathrm{Z2}(2)$ & 1.25 & 1.25 & 1.35 & $1.28 b c$ \\
\hline $\mathrm{Z3} \mathrm{(3)}$ & 1.28 & 1.30 & 1.35 & $1.31 b$ \\
\hline Z4 (4) & 1.35 & 1.35 & 1.38 & $1.36 \mathrm{~b}$ \\
\hline $\mathrm{Z} 5(5)$ & 1.40 & 1.40 & 1.45 & $1.42 \mathrm{ab}$ \\
\hline $\mathrm{Z6} \mathrm{(6)}$ & 1.45 & 1.45 & 1.75 & $1.55 \mathrm{a}$ \\
\hline Mean & $1.29 p$ & $1.31 p$ & $1.37 p$ & $(-)$ \\
\hline
\end{tabular}

Remarks: Means followed by the same letters in the same column are not significantly different based on DMRT at $\alpha 5 \%$.
Table 1 shows that increasing doses of zeolite can improve plant height. The application of $6 \%$ zeolite per weight of sandy soils resulted in the highest corn plants with a height of $165.05 \mathrm{~cm}$. Likewise, increasing doses of nitrogen fertilizer up to $100 \mathrm{~kg}$ per hectare can also increase plant height.

There was no interaction between zeolite and nitrogen fertilizer doses in affecting the growth of plant corn. Increasing the dose of zeolite is thought to increase water supply in the root zone and support the process of nitrogen nutrient uptake. The results of plant height measurements at an average dose of nitrogen fertilizer showed that the highest dose of zeolite $(6 \%$ per weight of $10 \mathrm{~kg}$ of sandy soils) produced the highest plants. This result is following the result by Sangeetha and Baskar (2016), reporting that the application of zeolite as a soil amendment material could increase the availability of water for plants in sandy soil. Besides, zeolite is beneficial in reducing the leaching rate of $\mathrm{N}$ element because the negative charge side of the zeolite surface can bind $\mathrm{NH}_{4}^{+}$ions (Omar et al., 2015), and reduce the transformation process to $\mathrm{NO}_{3}$ mobile ions in the soil solution system.

The same result was also observed on the stem diameter of the corn plants. The doses of zeolite and nitrogen fertilizer did not give significant interaction effect on the stem diameter of the corn plants (Table 2).

There was a significant effect of zeolite doses on the stem diameter of the corn plants. The application of $6 \%$ zeolite per weight of the sandy soils as planting media produced the largest stem diameter. Meanwhile, the doses of nitrogen fertilizer did not significantly affect the stem diameter of the corn plants.

Tables 1 and 2 show that at various doses of nitrogen fertilizer, an increase in the dose of zeolite can increase the availability of water for the nitrogen uptake process that occurs in the root zone. Zeolite is a hydrated aluminum mineral that 
has a three-dimensional structure formed by the tetrahedral $\left(\mathrm{SiO}_{4}\right)^{-4}$ and $\left(\mathrm{AlO}_{4}\right)^{-5}$ structures. These three-dimensional structures are interconnected so that they have canals and tunnels, and are generally negatively charged so that they can bind cations (Sugiarti and Amiruddin, 2008; Lestari, 2010). Therefore, zeolite application can improve the ability of sandy soils to store water and improve nutrient balance in sandy soils (Al-Busaidi et al., 2008).

The observation on the fresh weight of corn biomass showed that there was a significant interaction effect of zeolite and nitrogen fertilizer doses on vegetative growth. The effect of the combined treatment of zeolite and nitrogen fertilizer doses is presented in Table 3.

Table 3. Fresh Weight of Corn Plant Biomass (gram) at Eight Weeks After Planting

\begin{tabular}{ccccc}
\hline \multirow{2}{*}{$\begin{array}{c}\text { Zeolite } \\
\text { doses (\%) }\end{array}$} & $\begin{array}{c}\text { N1 } \\
\text { (75 kg/h) }\end{array}$ & $\begin{array}{c}\text { N2 } \\
(100 \mathrm{~kg} / \mathrm{h})\end{array}$ & $\begin{array}{c}\text { N3 } \\
(125 \mathrm{~kg} / \mathrm{h})\end{array}$ & \\
\hline Z0 (0) & $58.5 \mathrm{k}$ & $86.4 \mathrm{jk}$ & $110.6 \mathrm{ijk}$ & 85.2 \\
Z1 (1) & $121 \mathrm{hijk}$ & 156.6 efghi & $202.1 \mathrm{cdefg}$ & 159.9 \\
Z2 (2) & $137.7 \mathrm{ghij}$ & 165.8 defghi & 161.9 efghi & 155.1 \\
Z3 (3) & 165.3 defghi & 174.3 cdefghi & $146.5 \mathrm{fghij}$ & 162.0 \\
Z4 (4) & 156.8 efghi & 170.4 cdefghi & $238.8 \mathrm{C}$ & 188.7 \\
Z5 (5) & 211.2 cdef & $226.1 \mathrm{cde}$ & $234.4 \mathrm{~cd}$ & 223.9 \\
Z6 (6) & 183.4 cdefgh & $308.6 \mathrm{~b}$ & $435.7 \mathrm{a}$ & 309.2 \\
\hline Mean & 147.7 & 184.0 & 218.6 & $(+)$ \\
\hline
\end{tabular}

Remarks: Means followed by the same letters in the same column are not significantly different based on DMRT at $\alpha 5 \%$.

The application of nitrogen fertilizer at all doses $(75,100$, and $125 \mathrm{~kg}$ per hectare) without zeolite treatment produced the lowest weight of fresh biomass compared to other treatment combinations. Meanwhile, the application of 100 and $125 \mathrm{~kg}$ of nitrogen fertilizer per hectare, when combined with $6 \%$ zeolite per weight of the growing media, produced higher biomass fresh weight than the application of $75 \mathrm{~kg}$ of nitrogen per hectare.

The fresh weight of plant biomass is the weight of the entire plant tissues that have been developing for a certain time, along with the water contained. Plants that have better growth have cells containing more water. Table 3 shows that the treatment combination of zeolite and nitrogen fertilizer can improve the growth of plant cells and tissues. Zeolite can increase water supply and nitrogen nutrient uptake for the growth of plant cells and tissues. The addition of zeolite can suppress the rate of nitrification due to $\mathrm{NH}_{4}+$ ions and nitrogen leaching because it is bound by its specific surface (Ippolito et al., 2011), and this condition supports the process of nitrogen nutrient uptake of plants. The ability of zeolite to fix $\mathrm{NH}_{4}+$ ions and delay nitrification was also conveyed by Sudirja et al. (2016), reporting that mixing Urea and Zeolite (95:5) could increase the total nitrogen content of the soil.

Analysis of variance on the dry weight of plant biomass showed that there was no significant interaction effect of zeolite and nitrogen fertilizer doses on plant growth. However, each treatment significantly affected the dry weight of plant biomass (Table 4).

Increasing the dose of zeolite can significantly increase the dry weight of plant biomass. These data show that the availability of water in the root zone will guarantee the process of nitrogen nutrient uptake for the growth and development of corn plant cells and tissues. It is suspected that increasing the zeolite dose can create water sorption complexes in the root zone so that gravity water can be reduced, and the leaching of nitrogen compounds will also be reduced. The addition of zeolite turned out to be able to improve the insufficiency of sandy soil as a planting medium. The use of zeolite will increase water storage capacity and cation exchange capacity so that $\mathrm{N}$-ammonium nutrients can be stored. Experiments carried out by Aina et al. (2017) showed that the use of zeolite in corn plantations could increase the biomass of corn plants cultivated using NPK. Another experi- 
Table 4. Dry weight of corn plant biomass (gram) at eight weeks after planting

\begin{tabular}{|c|c|c|c|c|}
\hline \multirow{2}{*}{$\begin{array}{c}\text { Zeolite } \\
\text { doses (\%) }\end{array}$} & \multicolumn{3}{|c|}{ Nitrogen fertilizer doses } & \multirow[b]{2}{*}{ Mean } \\
\hline & $\begin{array}{c}\mathrm{N} 1 \\
(75 \mathrm{~kg} / \mathrm{h})\end{array}$ & $\begin{array}{c}\mathrm{N2} \\
(100 \mathrm{~kg} / \mathrm{h})\end{array}$ & $\begin{array}{c}\mathrm{N3} \\
(125 \mathrm{~kg} / \mathrm{h})\end{array}$ & \\
\hline $\mathrm{ZO}(0)$ & 9.65 & 12.80 & 14.78 & $12.41 \mathrm{~d}$ \\
\hline $\mathrm{Z1}(1)$ & 17.90 & 21.85 & 22.24 & $20.66 c$ \\
\hline $\mathrm{ZZ}(2)$ & 23.54 & 24.78 & 24.90 & $24.41 \mathrm{bc}$ \\
\hline $\mathrm{Z3} \mathrm{(3)}$ & 24.45 & 21.40 & 27.95 & $23.60 \mathrm{bc}$ \\
\hline Z4 (4) & 25.35 & 29.45 & 23.15 & $25.98 b$ \\
\hline $\mathrm{Z5}(5)$ & 26.46 & 26.18 & 33.18 & $28.61 \mathrm{~b}$ \\
\hline $\mathrm{Z6}(6)$ & 32.90 & 37.45 & 50.75 & $40.37 \mathrm{a}$ \\
\hline Mean & $22.89 q$ & $24.84 q$ & $28.14 p$ & $(-)$ \\
\hline
\end{tabular}

Remarks: Means followed by the same letters in the same column are not significantly different based on DMRT at $\alpha 5 \%$.

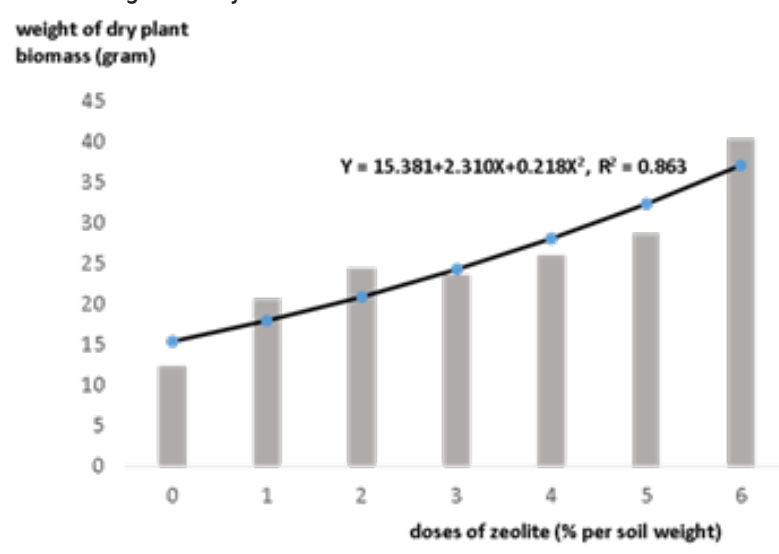

Figure 1. Effect of the Increasing Dose of Zeolite on the Dry Weight of Plant Biomass at Average Doses of Nitrogen Fertilizer

ment proved that the combination of $750 \mathrm{~kg}$ zeolite per hectare and $50 \mathrm{~kg}$ urea per hectare showed the best results on leaf area, plant height, and total dry weight of plants compared to $300 \mathrm{~kg}$ urea per hectare without zeolite (Widyanto et al., 2013).

The dry weight of plant biomass is the net weight of photosynthesis, largely determined by how much nutrients the plant can absorb. The fertilizer dose of $125 \mathrm{~kg}$ per hectare produced the highest dry weight of plant biomass. On the other hand, $125 \mathrm{~kg}$ of nitrogen fertilizer per hectare is the optimum dose for the growth of corn plants. The comparison of the dry weight of plant biomass produced by the three treatments shows that the addition of nitrogen fertilizer up to a certain dose can guarantee a better growth of plant cells and tissue.
Table 4 also shows that increasing the dose of zeolite at the average doses of nitrogen fertilizer can significantly increase the dry weight of plant biomass. The relationship between increasing zeolite dose at the average doses of nitrogen fertilizer and the increase of plant biomass dry weight is shown in Figure 1.

Figure 1 shows that at the average doses of nitrogen fertilizer, zeolite application can increase the dry weight of plant biomass. The presence of zeolite in the root zone proves to be able to increase water availability and nitrogen nutrient fixation, as well as to increase cell and plant tissue growth. The estimated curve on the effect of zeolite doses on plant biomass dry weight was formulated into a quadratic non-linear curve relationship pattern of $\mathrm{Y}=15.381+2.310 \mathrm{X}+0.218 \mathrm{X}^{2}$ with a determinant coefficient $\left(\mathrm{R}^{2}\right)$ of 0.863 . The curve shows that increasing the zeolite dose to above $6 \%$ per weight of the sandy soil could still increase the dry weight of plant biomass. The coefficient of determination of 0.863 indicates that an $86.3 \%$ increase in dry weight of plant biomass is determined by an increase in zeolite dose. The use of zeolite in the cultivation of annual crops such as mustard greens and sorghum can significantly increase the efficiency of nitrogen uptake (Bhaskoro et al., 2015; Suminarti, 2019).

\section{CONCLUSION}

The application of zeolite minerals to coastal sandy soils as planting media could increase the growth of nitrogen-fertilized corn plants. A dose of $6 \%$ zeolite per weight of $10 \mathrm{~kg}$ of coastal sandy soils as planting media produced the best vegetative growth. The combination of $6 \%$ zeolite and $125 \mathrm{~kg} \mathrm{~N}$ per hectare resulted in the highest fresh weight of plant biomass. Thus, the use of zeolite can increase the efficiency of nutrient uptake of $\mathrm{N}$-fertilizer in the vegetative growth of corn plants in coastal sandy soils. 


\section{REFERENCES}

Aina, N., Jumadi, O. dan Hiola S.F.(2017). Respon Pertumbuhan Jagung (Zea mays) dengan Pemberian Urea Bersalut Zeolit Sebagai Nitrogen Lepas Lambat. Jurnal Bionature, 7 (2): 152 - 162

Akhter, J., Mahmood, K., Malik, K.A., Mardan, A., Ahmad, M. and lqbal, M.M. (2004). Effects of Hydrogel Amendment on Water Storage of Sandy Loam and Loam Soils and Seedling Growth of Barley, Wheat and Chickpea. Plant Soil Environ., 50 (10): 463 - 469

Al-Busaidi, A., Yamamoto, T., Inoue, M., Eneji, A.E., Mori, Y. and Isrhad, M. (2008). Effects of Zeolite on Soil Nutrients and Growth of Barley Following Irrigation with Saline Water. The $3^{\text {rd }}$ International Conference on Water Resources and Arid Environments and the $1^{\text {st }}$ Arab Water Forum: $11 p$

Bruand, A., C. Hartmann and G. Lesturgez. (2014). Physical Properties of Tropical Sandy Soils: A Large Range of Behaviours. https://www.researchgate.net/publication/228982691_ Physical_properties_of_tropical_sandy_soils_A_large_range_ of_behaviours. 10p

Bhaskoro, A.W., Kusumarini, N. and Syekhfani. (2015). Efisiensi Pemupukan Nitrogen Tanaman Sawi pada Inceptisol melalui Aplikasil Zeolit Alam. Jurnal Tanah dan Sumberdaya Lahan, 2 (2) : $219-226$

Budiyanto, G. (2016). Pengendalian Pencucian Senyawa Nitrat Guna Meningkatkan Produktivitas Lahan Marginal Pantai Kulon Progo DIY. Planta Tropika Journal of Agro Science, 4 (1): 46- 57.

Director-General of Food Crops and Horticulture. (1998). Pemanfaatan Zeolit Sebagai Pengikat Urea. Publikasi No. PR.130.760.11

Harsojuwono,B.A., Arnata I Wayan dan Puspawati,G.A.K.D., (2011). Rancangan Percobaan, Teori Aplikasi SPSS dan Excel. Penerbit Lintaskata. 147p

Hoa, H.T.T., Cong, P.T., Tam, H.M., Chen, W. and Bell, R. (2010). Sandy soils in South Central Coastal Vietnam: Their Origin, Constraints and Management in 19th World Congress of Soil Science, Soil Solutions for a Changing World. 1 - 6 August 2010, Brisbane, Australia, 251-254

Ippolito, J.A., Tarkalson, D.D. and Lehrsch, G.A. (2011). Zeolite Soil Application Method Affects Inorganic Nitrogen, Moisture, and Corn Growth. Soil Science, 176 (3): 136 - 142

Lestari, D.Y. (2010). Kajian Modifikasi dan Karakterisasi Zeolit Alam dari berbagai Negara. Prosiding Seminar Nasional Kimia dan Pendidikan Kimia 2010. www.kimia.uny.ac.id.
Mahesh, M., Thomas, J., Kumar, K.A., Bhople, B.S., Saresh, N.V., Vaid, S.K. and Sahu, S.K. (2018). Zeolite Farming: A Sustainable Agricultural Prospective. International Journal of Current Microbiology and Applied Sciences, 7 (5): 2912 - 2924

Omar, L., Ahmed, O.H., and Majid, N.M.A. (2015). Improving Ammonium and Nitrate Release from Urea Using Clinoptilolite Zeolite and Compost Produced from Agricultural Wastes. Hindawi Publishing Corporation Scientific World Journal, 2015:12

Sangeetha, C. and Baskar, P. (2016). Zeolite and its Potential Uses in Agriculture: A critical review. Agricultural Reviews, 37 (2): 101-108

Sudirja, R., Joy ,B., Rosniawaty, S., Setiawan, A. dan Yunianto, R.I. (2016). Pengaruh Formula Pupuk Urea-Zeolit-Arangaktif terhadap pH, N-total, KTK tanah dan Residu Pb pada Tanah Tercemar Limbah Industri. Soilrens, 14 (1): 16 - 22

Sugiarti dan Amiruddin, S.Z.(2008). Pengaruh Jenis Aktivasi terhadap Kapasitas Adsorpsi Zeolite pada Ion Kromium. Jurnal Chemica, 4 (2): 20-25

Suminarti,N.E. (2019). Dampak Pemupukan N dan Zeolit pada Pertumbuhan serta Hasil Tanaman Sorgum (Sorghum bicolour L.) Var. Super 1. Jurnal Agro, 6 (1): 1 - 14

Tahir, S. and Marschnerm, P. 2016. Clay Addition to Sandy Soil - Effect of Clay Concentration and Ped Size on Microbial Biomass and Nutrient Dynamics after Addition of Low C/N ratio Residue. Journal Soil Science and Plant Nutrition 16 (4): 864 - 875

Widyanto, A., Sebayang, H.T. and Soekartomo, S.2013. Pengaruh Pengaplikasian Zeolit dan Pupuk Urea pada Pertumbuhan dan Hasil Tanaman Jagung Manis (Zea mays L. saccharata Sturt.). Jurnal Produksi Tanaman, 1 (4): 378 - 388

Wu,Q., Chi,D., Xia, G., Chen, T., Sun, Y. and Song, Y. 2019. Effects of Zeolite on Drought Resistance and Water-Nitrogen Use Efficiency in Paddy Rice. Journal of Irrigation and Drainage Engineering, 54 (11): 04019024

Zheng, J., Chen, T., Chi, D., Xia ,G., Liu, G., Chen, W., Meng, W., Chen, Y. and Siddique, K.H.M. (2019). Influence of Zeolite and Phosphorus Applications on Water Use, P Uptake and Yield in Rice under Different Irrigation Managements. Agronomy 9 (9): 537 